\title{
Odontogenic facial cellulitis
}

\author{
Tatsuro Sugai [1] , Wataru Nishie
}

Dermatology, Hokkaido University Graduate School of Medicine, Sapporo, Japan

\section{Correspondence to}

Dr Tatsuro Sugai;

28th.sugai@gmail.com

Accepted 28 November 2020

Check for updates

(c) BMJ Publishing Group Limited 2020. No commercial re-use. See rights and permissions. Published by BMJ.

\begin{tabular}{|l|}
\hline To cite: Sugai T, \\
Nishie W. BMJ Case \\
Rep 2020;13:e239381. \\
doi:10.1136/bcr-2020- \\
239381
\end{tabular}

\section{DESCRIPTION}

A 59-year-old man with angina visited our department with fever and facial pain. Clinically, his left cheek showed diffuse swelling with slight erythema (figure 1A). There was no toothache, although tooth contamination and gingival swelling were observed in the maxilla (figure 1B). CT findings revealed osteolysis of the root of a tooth, but there is no maxillary sinusitis.

We diagnosed facial cellulitis associated with apical periodontitis. Puncture drainage through the apex and systemic antibiotics quickly improved the symptoms.

Facial cellulitis can occur due to acute sinusitis, apical periodontitis, otitis externa, trauma, insect bites, conjunctivitis or blepharitis. It should be noted that the odontogenic infection is sometimes asymptomatic.

Therefore, clinicians should pay careful attention to the medical history and oral examination of patients with facial cellulitis. ${ }^{1}$

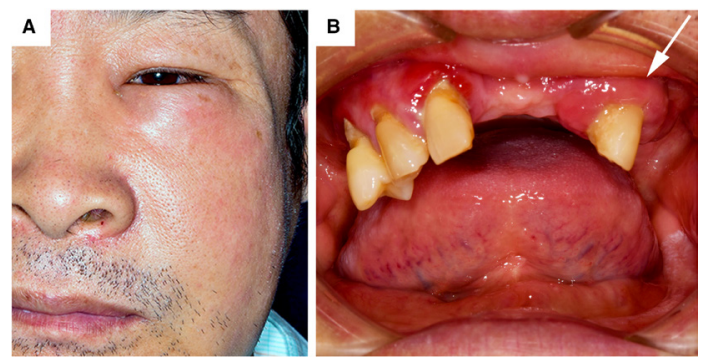

Figure 1 (A) Diffuse swelling with slight erythema was observed on his left cheek. (B) Tooth contamination and gingival swelling were observed in the maxilla (white arrow).

\section{Patient's perspective}

I visited to the hospital because my face was swollen, but I didn't think it was due to caries because there is no pain in my teeth.

\section{Learning points}

- In cases of facial cellulitis, it can arises from acute sinusitis, apical periodontitis, otitis externa, trauma, insect bites, conjunctivitis or blepharitis.

- Odontogenic infections are sometimes asymptomatic and easily missed as infected foci.

Contributors I, TS, am the first author of this article, and my works included examining and treating patients, writing the manuscript, preparing the figure and obtaining patient consent. WN was a co-author of this paper and contributed to advising on the diagnosis, reviewing the submissions and preparing the text.

Funding The authors have not declared a specific grant for this research from any funding agency in the public, commercial or not-for-profit sectors.

Competing interests None declared.

Patient consent for publication Obtained.

Provenance and peer review Not commissioned; externally peer reviewed.

\section{ORCID iD}

Tatsuro Sugai http://orcid.org/0000-0002-2522-7661

\section{REFERENCE}

1 Wahie S, Vadhera S, Meggitt SJ. Facial cellulitis as the presenting manifestation of a painless dental abscess. J Eur Acad Dermatol Venereol 2006;20:1388-9.
Copyright 2020 BMJ Publishing Group. All rights reserved. For permission to reuse any of this content visit

https://www.bmj.com/company/products-services/rights-and-licensing/permissions/

BMJ Case Report Fellows may re-use this article for personal use and teaching without any further permission.

Become a Fellow of BMJ Case Reports today and you can:

- Submit as many cases as you like

- Enjoy fast sympathetic peer review and rapid publication of accepted articles

- Access all the published articles

- Re-use any of the published material for personal use and teaching without further permission

\section{Customer Service}

If you have any further queries about your subscription, please contact our customer services team on +44 (0) 2071111105 or via email at support@bmj.com.

Visit casereports.bmj.com for more articles like this and to become a Fellow 